\title{
PENGARUH TEKNIK RELAKSASI OTOT PROGRESIF TERHADAP PENURUNAN TEKANAN DARAH PADA LANSIA PENDERITA HIPERTENSI DI PUSKESMAS MULIOREJO TAHUN 2020
}

\author{
Megawati \\ Jurusan Keperawatan, Politeknik Kesehatan Kemenkes Medan \\ e-mail:hj.megawati1963@gmail.com
}

\begin{abstract}
Elderly begin to experience a decrease in function one of which in the circulatory system. Decreased elasticity of blood vessel walls which can cause an increase in blood pressure. One of the handling efforts that can be done to reduce blood pressure is progressive muscle relaxation therapy. Progressive muscle relaxation therapy in elderly aims to elicit a relaxation response that can stimulate the activity of sympathetic and parasympathetic nerves resulting in a decreasein blood pressure in the elderly. This study aims to determine the effect of progressive muscle relaxation techniques on reducing blood pressure in the elderly at Elderly Social Services of Muliorejo. The research method used was Pre - Post Test Design Experiments which aimed to determine the effect of progressive muscle relaxation techniques on blood pressure reduction in the elderly at Elderly Social Services of Muliorejo. The Population in this study amounted to 55 elderly. The method of taking samples using Purposive Sampling and get a sample of 35 respondents. This study used a logistic regression test with $a=0.05$. The results of the study were 1) before doing muscle relaxation there were 22 people (62.9\% 0 categorized as having hypertension with stage I level (systolic 140$159 \mathrm{mmHg} /$ distolic $90-99 \mathrm{mmHg}$ ). 2) after doing relaxation there were 8 people (22,3\%) categorized blood pressure under prehipertensi conditions that was prehipertensi blood pressure (systolic 120-139 $\mathrm{mmHg} /$ distolic 80-89 $\mathrm{mmHg}$ ), 3) there was an effect of progressive muscle relaxation technique on reducing hypertension in the elderly at Elderly Social Services of Muliorejo as evidenced by Sig, $=0.000$. The conclusion can be stated that there was an effect of progressive muscle relaxation technique on reducing blood pressure in Elderly Social Services of Muliorejo. Suggestions for respondents are expected to be able to apply progressive muscle relaxation technique as herbal treatment therapies.
\end{abstract}

Keywords: Hypertension, Progressive Muscle Relaxation Technique, Blood Pressur

\section{ABSTRAK}

Lanjut usia mulai mengalami penurunan fungsi salah satunya pada sistem peredaran darah. Penurunan elastisitas dinding pembuluh darah yang dapat menyebabakan peningkatan tekanan darah. Salah satu upaya penanganan yang dapat dilakukan untuk menurunkan tekanan darah adalah terapi relaksasi otot progresif. terapi relaksasi otot progresif pada lanjut usia bertujuan untuk memunculkan respon relaksasi yang dapat merangsang aktivitas saraf simpatis dan parasimpatis sehingga terjadi penurunan tekanan darh pada lanjut usia. Penelitian ini bertujuan untuk mengetahui pengaruh teknik relaksasi otot progresif terhadap penurunan tekanan darah pada lansia di Puskesmas Muliorejo. Metode penelitian yang digunakan adalah Pra Eksperimen Design Group Pre-Post Test Design yang bertujuan untuk mengetahui pengaruh teknik relaksasi otot progresif terhadap penurunan tekanan darah pada lansia di Puskesmas Muliorejo. Populasi dalam penelitian ini berjumlah 55 lansia. Metode pengambilan sample menggunakan Purposive sampling dan dapatkan sampel sebanyak 35 responden. Penelitian ini menggunakan uji regresi logistik dengan $\alpha=0,05$. Hasil penelitian adalah 1) sebelum dilakukannya relaksasi otot terdapat 22 orang (62.9\%) dikategorikan mengalami hipertensi dengan tingkat stage 1 (sistolik140-159 mmHg / distolik 90-99 mmHg). 2) Sesudah dilakukannya relaksasi terdapat 8 orang (22.9\%) dikategorikan tekanan darah dalam kondisi Prehipertensi yaitu tekanan darah normal (sistolik 120-139 mmHg / distolik 80-89 mmHg), 3) Terdapat pengaruh teknik relaksasi otot progresif terhadap penurunan hipertensi pada lansia di Puskesmas Muliorejo yang dibuktikan dengan nilai Sig. $=0,000$.

Kesimpulan maka dapat dinyatakan bahwa ada pengaruh teknik relaksasi otot progresif terhadap penurunan tekanan darah pada lansia di Puskesmas Muliorejo. Sarannya bagi responden diharapkan dapat menerapkan teknik relaksasi otot progresif sebagai terapi pengobatan.

Kata kunci : Hipertensi, Teknik relaksasi otot Progresif, Tekanan darah.

\section{PENDAHULUAN}

Menurut World Health Organization (WHO) lanjut usia adalah kelompok penduduk yang usia diatas 60 tahun. Secara global pada tahun 2013 proporsi dari populasi penduduk usia diatas 60 tahun adalah $11,7 \%$ dari total populasi dunia dapat diprediksi jumlah akan terus meningkat seiring dengan peningkatan usia harapan hidup (Rismawati, 2013).

Indonesia merupakan Negara dengan populasi di atas 7\% dari keseluruhan penduduk. jumlah penduduk lansia berdasarkan data proyeksi penduduk, diperkirakan tahun 2017 terdapat 23,66 juta jiwa penduduk lansia di Indonesia $(9,03 \%)$. diprediksi 
jumlah penduduk lansia tahun 2020 (27,08 juta), tahun $2025(33,69)$, tahun $2030(40,95)$, dan tahun 2035 (48.19) (Kementrian kesehatan RI, 2017).

Menurut Profil Kesehatan Sumatera Utara tahun 2017 komposisi penduduk Sumatera Utara menurut kelompok umur menunjukkan bahwa penduduk berusia tua (>65 tahun) sebesar 4,28\% (Dinas Kesehatan Sumatera Utara, 2017). Menurut Profil Kesehatan Medan Tahun 2016 komposisi penduduk Medan menurut kelompok umur menunjukkan bahwa penduduk berusia tua ( $>65$ tahun) sebesar 3,82\% (Kesehatan \& Medan, 2016). Profil Kesehatan Binjai Tahun 2016 komposisi penduduk Binjai menurut kelompok umur menunjukkan bahwa penduduk berusia tua (>65 tahun) sebesar $4,3 \%$ (Kesehatan Kota Binjai, 2016). Berdasarkan hasil survey awal yang dilakukan peneliti di Puskesmas Muliorejo Pemprovsu 2018 jumlah lansia sebanyak 160 lansia, yang menderita asam urat 66 jiwa sebesar $31,2 \%$, hipertensi 55 jiwa sebesar 26,0\%, katarak 39 jiwa sebesar $18,4 \%$, asma 10 jiwa sebesar $4,7 \%$, dyspepsia 10 jiwa sebesar $4,7 \%$, diabetes melitus 8 jiwa sebesar 3,7\%, rematik 8 jiwa sebesar 3,7\%.

Lansia merupakan kelompok yang rentan sekali terkena penyakit menular ataupun tidak menular karena dengan bertambahnya umur seseorang akan mengalami penurunan atau perubahan fungsi seperti fisik, psikis, biologis, spiritual, serta hubungan sosialnya, dan tentunya memberikan pengaruh terhadap berbagai aspek kehidupanya. Salah satunya kondisi kesehatanya, World Population Prospect (2010) dalam KemenKesRI (2013) menyebutkan bahwa populasi lansia di dunia tahun 2010 mencapai 14,35\% dari total penduduk dunia (Fitrianti, 2018).

Hipertensi adalah penyakit yang terjadi akibat peningkatan tekanan darah sistolik dan diastolik dengan konsisten diatas 140/90 mmHg (Baradero, Dayrit, \& Siswadi, 2008). Hipertensi merupakan faktor yang berkonstribusi terhadap kematian akibat stroke dan faktor yang memperberat infark miokard (serangan jantung). Kondisi tersebut merupakan gangguan asimptomatik yang sering terjadi ditandai dengan peningkatan tekanan darah secara persisten (Tyani S, 2015).

Data dari World Health Organization (2014), satu milyar orang di dunia menderita hipertensi, 2/3 diantaranya berada di negara berkembang yang berpenghasilan rendah sampai dengan sedang. Prevalensi hipertensi akan terus meningkat tajam, diprediksi pada tahun 2025 sebanyak 29\% orang dewasa di seluruh dunia terkena hipertensi. Hipertensi telah mengakibatkan kematian sekitar 8 juta orang setiap tahun (Khairiyah Wahyuningsih, 2018).

Jumlah penderita hipertensi terus meningkat seiring dengan jumlah penduduk yang membesar, prevalensi dunia mencapai $29,2 \%$ pada laki-laki dan $24 \%$ pada perempuan (WHO, 2012). Data Global Status Report on Noncommunicable Disesases 2010 menyebutkan, $40 \%$ negara ekonomi berkembang memiliki penderita hipertensi, sedangkan negara maju hanya $35 \%$. Kawasan Afrika memegang posisi puncak penderita hipertensi sebanyak $46 \%$ dan dikawasan Asia Tenggara $36 \%$ orang dewasa menderita hipertensi (Tyani S, 2015).

Hipertensi merupakan penyebab kematian nomor 3 di Indonesia setelah stroke dan tuberkolusis, yakni mencapai $6,7 \%$ dari total kematian pada semua umur (Khairiyah Wahyuningsih, 2018).

Pada orang lanjut usia penyebab hipertensi disebabkan terjadinya perubahan pada penurunan elastisitas dinding aorta, katup jantung menebal dan menjadi kaku, kemampuan jantung memompa darah, kehilangan elastisitas pembuluh darah dan meningkatnya resistensi pembuluh darah perifer. Setelah usia 20 tahun kemampuan jantung memompa darah menurun $1 \%$ tiap tahun sehingga menyebabkan menurunnya kontraksi dan volume (Aspiani, 2014). Selain penurunan fisiologis sistem kardiovaskuler seorang lanjut usia juga telah menghadapi banyak situasi yang penuh tekanan dalam kehidupan seharihari yang menimbulkan respons individu (Firianti, 2018).

Solusi untuk menurunkan tekanan darah tinggi dapat dilakukan dengan cara farmokologi (dengan obat) dan nonfarmokologi (tanpa obat). Dengan menggunakan obat, tentu ada efek jangka panjang, pengobatan alternative menjadi pilihan beberapa orang untuk mengatasi hipertensi, salah satunya melakukan terapi herbal yang telah diakui kalangan medis untuk mengobati gangguan hipertensi bahkan ada keuntungannya, karena terapi herbal tidak memiliki efek samping. Beberapa terapi teknik relaksasi termaksud yaitu yoga, relaksasi otot progresif, dan relaksasi nafas dalam dapat penurunan tekanan darah hipertensi (Tyani S, 2015).

Salah satu teknik relaksasi yang sering digunakan adalah teknik Relaksasi Otot Progresif (Progressive Muscular Relaxation (PMR] sebagai terapi untuk membantu meredakan beberapa gejala yang berkaitan dengan stress. Insomnia dan Hipertensi. Teknik relaksasi otot progresif adalah memusatkan perhatian pada suatu aktivitas otot, dengan mengidentifikasikan otot yang tegang kemudian menurunkan ketegangan dengan melakukan teknik relaksasi untuk mendapatkan perasaan relaks. Respon relaksasi merupakan bagian dari penurunan umum kognitif, fisiologis, dan stimulasi perilaku. Relaksasi dapat merangsang munculnya zat kimia yang mirip dengan beta blocker di saraf tepi yang dapat menutup simpul-simpul saraf simpatis yang berguna untuk mengurangi ketegangan dan menurunkan tekanan darah (Tyani S, 2015).

Berdasarkan penelitian (Tyani S, 2015) menyatakan bahwa adanya efektivitas relaksasi otot progresif terhadap penurunan tekanan darah dimana sebelum pemberian intervensi didapatkan penderita hipertensi rerata adalah $156,60 \mathrm{mmHg}$ dan tekanan darah diastolik rerata sebesar $94,47 \mathrm{mmHg}$ dan setelah pemberian intervensi didapatkan penderita hipertensi reratanya adalah $146,53 \mathrm{mmHg}$ dan tekanan darah diastolik rerata sebesar $88,20 \mathrm{mmHg}$. 
Berdasarkan penelitian (Nursyahidah, 2016) menyatakan bhwa adanya pengaruh tekhnik relaksasi otot progresif terhadap penurunan tekanan darah dimana sebelum pemberian intervensi didapatkan penderita hipertensi reratanya adalah $148,50 \mathrm{mmHg}$ dan tekanan darah diastolik rerata sebesar 94,41 $\mathrm{mmHg}$ dan setelah pemberian intervensi didapatkan penderita hipertensi reratanya adalah $142,75 \mathrm{mmHg}$ dan tekanan darah diastolik didapatkan rerta sebesar 91,25 $\mathrm{mmHg}$.

Berdasarkan penelitian (Ulya Inayatul \& Faidah, 2017) menyatakan bahwa adanya pengaruh terapi relaksasi otot progresif terhadap penurunan tekanan darah dimana sebelum pemberian intervensi didapatkan penderita hipertensi pada kelompok eksperimen reratanya adalah $163,06 \mathrm{mmHg}$ dan tekanan darah diastolik rerata sebesar $101,46 \mathrm{mmHg}$, sedangkan kelompok kontrol reratanya adalah sebesar $167,40 \mathrm{mmHg}$ dan tekanan darah diastolik rerata sebesar 96,86 mmHg dan setelah pemberian intervensi didapatkan penderita hipertensi kelompok eksperimen reratanya adalah $161,00 \mathrm{mmHg}$ dan tekanan darah diastolik rerata sebesar $99,33 \mathrm{mmHg}$, sedangkan kelompok kontrol reratanya adalah sebesar 168,60 $\mathrm{mmHg}$ dan tekanan darah diastolik rerata sebesar 97,73 $\mathrm{mmHg}$

Berdasarkan penelitian (Fitrianti, 2018) menyatakan bahwa adanya pengaruh relaksasi otot progresif terhadap penurunan tekanan darah dimana sebelum pemberian intervensi didapatkan penderita hipertensi reratanya adalah $149,25 \mathrm{mmHg}$ dan tekanan darah diastolik rerata sebesar 97,50 $\mathrm{mmHg}$ dan setelah pemberian intervensi didapatkan penderita hipertensi reratanya adalah $118,50 \mathrm{mmHg}$ dan tekanan darah diastolik didapatkan rerata sebesar $86,50 \mathrm{mmHg}$.

Berdasarkan penelitian (Khairiyah Wahyuningsih, 2018) menyatakan bahwa adanya pengaruh terapi relaksasi otot progresif terhadap penurunan tekanan darah dimana sebelum pemberian intervensi didapatkan penderita hipertensi pada kelompok perlakuan reratanya adalah $168,82 \mathrm{mmHg}$ dan tekanan darah diastolik rerata sebesar 24,29 $\mathrm{mmHg}$, sedangkan kelompok kontrol reratanya adalah sebesar $167,91 \mathrm{mmHg}$ dan tekanan darah diastolik rerata sebesar $24,40 \mathrm{mmHg}$ dan setelah pemberian intervensi didapatkan penderita hipertensi kelompok eksperimen reratanya adalah $89,86 \mathrm{mmHg}$ dan tekanan darah diastolik rerata sebesar $15,78 \mathrm{mmHg}$, sedangkan kelompok kontrol reratanya adalah sebesar 88,05 $\mathrm{mmHg}$ dan tekanan darah diastolik rerata sebesar 16,22 $\mathrm{mmHg}$.

\section{METODE}

Jenis penelitian ini adalah penelitian pra eksperimen dengan desain one group pre-post test design dan dilakukan pada bulan September 2020. Jumlah populasi merupakan subjek di dalam penelitian ini yaitu sebanyak 55 lansia, adapun jumlah sampel pada penelitian ini berjumlah 35 sesudah dan sebelum dilakukan perlakuan. Alat untuk pengumpulan data adalah Data Primer adalah data yang diambil langsung dari lapangan dengan melakukan survei (observasi) untuk melihat tekanan darah pada penderita hipertensi pada lansia. Data sekunder adalah data yang diperoleh dengan cara mengumpulkan informasi dari Puskesmas Muliorejo Tahun 2020. Cara Pengumpulan Data merupakan suatu proses pendekatan subjek dan proses mengumpulkan karakteristik subjek yang akan dibutuhkan dalam penelitian. Data yang telah dikumpulkan diolah dengan análisis univariat, bivariat.

HASIL

Tabel 4.1

Distribusi Frekuensi Karakteristik Responden Berdasarkan Umur Pada Penderita Hipertensi di Puskesmas Muliorejo

\begin{tabular}{|l|c|c|c|}
\hline No. & Umur & $\mathrm{n}$ & $\%$ \\
\hline 1 & $20-45$ tahun & 1 & 2,86 \\
\hline 2 & $46-65$ tahun & 16 & 45,71 \\
\hline 3 & $>66$ tahun & 18 & 56,47 \\
\hline & Jumlah & $\mathbf{3 5}$ & $\mathbf{1 0 0 . 0 0}$ \\
\hline
\end{tabular}

Berdasarkan data pada Tabel 4.2 diketahui distribusi responden berdasarkan umur pasien, sebagian besar responden memiliki umur > 66 tahun sebanyak 18 orang $(56,47 \%)$, responden dengan umur 46-65 tahun sebanyak 16 orang $(45,71 \%)$ dan responden dengan umur 20-45 tahun sebanyak 1 orang $(2,86 \%)$

Tabel 4.2

Distribusi Frekuensi Karakteristik Responden Berdasarkan Jenis Kelamin Pada Penderita Hipertensi di Puskesmas Muliorejo

\begin{tabular}{|c|l|c|c|}
\hline No. & Jenis Kelamin & $\mathrm{n}$ & $\%$ \\
\hline 1 & Pria & 17 & 45,53 \\
\hline 2 & Wanita & 18 & 56,47 \\
\hline
\end{tabular}

Berdasarkan data pada tabel 4.1 diketahui distribusi responden berdasarkan jenis kelamin responden, sebagian besar responden jenis kelamin wanita sebanyak 18 orang $(56,47 \%)$ dan responden dengan jenis kelamin pria sebanyak 17 orang $(45,53 \%)$.

Tabel 4.3

Distribusi Responden Berdasarkan Pengukuran TD Sistolik Pre Intervensi Pada Penderita Hipertensi di Puskesmas Muliorejo

\begin{tabular}{|c|c|c|c|c|c|c|c|}
\hline \multirow[t]{2}{*}{ No } & \multirow{2}{*}{$\begin{array}{l}\text { Pelaksanaan } \\
\text { Relaksasi }\end{array}$} & \multirow[b]{2}{*}{ Prehipertensi } & \multicolumn{3}{|c|}{ Pengukuran Tekanan Darah } & \multirow[b]{2}{*}{ Stage } & \multirow[b]{2}{*}{$\%$} \\
\hline & & & $\%$ & Stage & $\%$ & & \\
\hline & & & & 1 & & 2 & \\
\hline 1 & Hari Pertama & $0^{\prime}$ & 0.0 & 0 & 0.00 & 35 & 100.0 \\
\hline 2 & Hari Kedua & 33 & 94.3 & $0^{\prime}$ & 0.00 & 2 & 5.7 \\
\hline 3 & Hari Ketiga & $0^{\prime \prime}$ & 0.0 & $14^{\prime}$ & 40.0 & $21^{\prime}$ & 60.0 \\
\hline 4 & Hari Keempat & 1 & 2.9 & 20 & 57.1 & 14 & 40.0 \\
\hline 5 & Hari Kelima & 4 & 11.4 & 20 & 57.1 & 11 & 31.4 \\
\hline 6 & Hari Keenam & 12 & 34.3 & 22 & 62.9 & 1 & 2.9 \\
\hline
\end{tabular}

Berdasarkan data pada tabel 4.3 diketahui distribusi responden berdasarkan pengukuran TD Sistolik Pre Intervensi, sebagian besar responden memiliki TD Stage 2 sebanyak 35 orang (100,00\%), pada hari pertama, sebanyak 21 orang $(60,0 \%)$ pada hari ketiga, sebanyak 14 orang $(40.0 \%)$ pada hari keempat, sebanyak 11 orang $(31.4 \%)$ pada hari kelima. Selanjutnya memiliki TD Prehipertensi sebanyak 33 orang $(94,3 \%)$ pada hari kedua, sebanyak 12 orang 
(34.3\%) pada hari keenam dan sebanyak 4 orang (11.4\%) pada hari kelima. Sedangkan memiliki TD Stage 1 sebanyak 14 orang $(40,0 \%)$ pada hari ketiga, sebanyak 20 orang $(57.1 \%)$ pada hari keempat, sebanyak 20 orang $(57.1 \%)$ pada hari kelima dan sebanyak 22 orang $(62.9 \%)$ pada hari keenam.

Tabel 4.4.

Distribusi Responden Berdasarkan Pengukuran TD Diastolik Pre Intervensi Pada Penderita Hipertensi di Puskesmas Muliorejo

\begin{tabular}{|c|c|c|c|c|c|c|c|}
\hline \multirow[t]{3}{*}{ No } & \multirow{2}{*}{$\begin{array}{l}\text { Pelaksanaan } \\
\text { Relaksasi }\end{array}$} & \multicolumn{6}{|c|}{ Pengukuran Tekanan Darah } \\
\hline & & Prehipertensi & $\%$ & Stage & $\%$ & Stage & $\%$ \\
\hline & & & & 1 & & 2 & \\
\hline 1 & Hari Pertama & 3 & 8.6 & 16 & 45.7 & 16 & 45.7 \\
\hline 2 & Hari Kedua & 3 & 8.6 & 24 & 68.6 & 8 & 22.9 \\
\hline 3 & Hari Ketiga & $0^{\prime}$ & 0.0 & 1 & 2.9 & 34 & 97.1 \\
\hline 4 & Hari Keempat & 13 & 37.1 & 13 & 37.1 & 9 & 25.7 \\
\hline 5 & Hari Kelima & 21 & 60 & 5 & 14.3 & 9 & 25.7 \\
\hline 6 & Hari Keenam & 27 & 77.1 & $0^{\prime}$ & 0.0 & 8 & 22.9 \\
\hline
\end{tabular}

Berdasarkan data pada tabel 4.4 diketahui distribusi responden berdasarkan pengukuran TD Diastolik Pre Intervensi, sebagian besar responden memiliki TD Stage II sebanyak 34 orang $(97,1 \%)$ pada hari ketiga, sebanyak 16 orang $(45,7 \%)$ pada hari pertama, sebanyak 9 orang $(25.7 \%)$ pada hari keempat dan hari kelima, sebanyak 8 orang $(22.9 \%)$ pada hari kedua dan hari keenam. Selanjutnya memiliki RD Prehipertensi sebanyak 27 orang $(77,1 \%)$ pada hari keenam, sebanyak 21 orang $(80.0 \%)$ pada hari kelima, sebanyak 13 orang (37.1) pada hari keempat dan masing-masing sebanyak 3 orang (8.6) pada hari pertama dan hari kedua. Sedangkan memiliki RD Stage I sebanyak 24 orang $(68,6 \%)$ pada hari kedua, sebanyak 16 orang $(45.7 \%)$ pada hari pertama, sebanyak 13 orang $(37.1 \%)$ pada hari keempat sebanyak 22 orang $(62.9 \%)$ pada hari keenam.

Tabel 4.5

Distribusi Responden Berdasarkan Pengukuran TD Sistolik Post Intervensi Pada Penderita Hipertensi di Puskesmas Muliorejo

\begin{tabular}{|c|c|c|c|c|c|c|c|}
\hline \multirow[t]{3}{*}{ No } & \multirow{2}{*}{$\begin{array}{l}\text { Pelaksanaan } \\
\text { Relaksasi }\end{array}$} & \multicolumn{6}{|c|}{ Pengukuran Tekanan Darah } \\
\hline & & Prehipertensi & $\%$ & Stage & $\%$ & Stage & $\%$ \\
\hline & & & & 1 & & 2 & \\
\hline 1 & Hari Pertama & 0 & 0.0 & 2 & 5.7 & 33 & 94.3 \\
\hline 2 & Hari Kedua & 0 & 0.0 & 5 & 14.3 & 30 & 85.7 \\
\hline 3 & Hari Ketiga & 0 & 0.0 & 12 & 34.3 & 23 & 65.7 \\
\hline 4 & Hari Keempat & 1 & 2.9 & 20 & 57.1 & 14 & 40 \\
\hline 5 & Hari Kelima & 10 & 28.6 & 1 & 2.9 & 2 & 5.7 \\
\hline 6 & Hari Keenam & 0 & 0.0 & 8 & 22.9 & 27 & 77.1 \\
\hline
\end{tabular}

Berdasarkan data pada Tabel 4.5 diketahui distribusi responden berdasarkan pengukuran TD Diastolik Post Intervensi, sebagian besar responden memiliki TD Stage II sebanyak 33 orang $(94,3 \%)$ pada hari pertama, sebanyak 30 orang $(85,7 \%)$ pada hari kedua, sebanyak 23 orang $(65.7 \%)$ pada hari ketiga, sebanyak 14 orang $(40.0 \%)$ pada hari keempat, sebanyak 2 orang (5.7\%) pada hari kelima dan sebanyak 27 orang $(77.1 \%)$ pada hari keenam. Selanjutnya memiliki RD Prehipertensi sebanyak 10 orang $(28,6 \%)$ pada hari kelima, sebanyak 1 orang (2.9\%) pada hari keempat. Sedangkan memiliki RD Stage I sebanyak 20 orang $(57,1 \%)$ pada hari keempat, sebanyak 12 orang $(34.3 \%)$ pada hari ketiga, sebanyak 8 orang $(22.9 \%)$ pada hari keenam, sebanyak 5 orang $(14.3 \%)$ pada hari kedua.

Tabel 4.6

Distribusi Responden Berdasarkan Pengukuran TD Diastolik Post Intervensi Pada Penderita Hipertensi di Puskesmas Muliorejo

\begin{tabular}{|c|c|c|c|c|c|c|c|}
\hline \multirow[t]{3}{*}{ No } & \multirow{2}{*}{$\begin{array}{l}\text { Pelaksanaan } \\
\text { Relaksasi }\end{array}$} & \multicolumn{6}{|c|}{ Pengukuran Tekanan Darah } \\
\hline & & Prehipertensi & $\%$ & Stage & $\%$ & Stage & $\%$ \\
\hline & & & & 1 & & 2 & \\
\hline 1 & Hari Pertama & 2 & 5.7 & 18 & 51.4 & 15 & 42.9 \\
\hline 2 & Hari Kedua & 5 & 14.3 & 23 & 65.7 & $7^{\prime}$ & 20.0 \\
\hline 3 & Hari Ketiga & $7^{\prime}$ & 20.0 & 24 & 68.6 & 4 & 11.4 \\
\hline 4 & Hari Keempat & 0 & 0.0 & 13 & 37.1 & 22 & 62.9 \\
\hline 5 & Hari Kelima & 32 & 91.4 & 1 & 2.9 & 2 & 5.7 \\
\hline 6 & Hari Keenam & $0^{\prime}$ & 0.0 & $0^{\prime \prime}$ & 0.0 & 0 & 0.0 \\
\hline
\end{tabular}

Berdasarkan data pada Tabel 4.6 diketahui distribusi responden berdasarkan pengukuran TD Diastolik Post Intervensi, sebagian besar responden memiliki TD Stage II sebanyak 22 orang $(62,9 \%)$, pada hari keempat, sebanyak 15 orang 42,9\%) pada hari pertama, sebanyak 7 orang $(20.0 \%)$ pada hari kedua, sebanyak 4 orang $(11.4 \%)$ pada hari ketiga dan sebanyak 2 orang (5.7\%) pada hari kelima. Selanjutnya memiliki RD Prehipertensi sebanyak 32 orang $(91,4 \%)$ pada hari kelima, sebanyak 7 orang $(20.0 \%)$ pada hari ketiga, sebanyak 5 orang $(14.3 \%)$ pada hari kedua dan sebanyak 2 orang $(5.7 \%)$ pada hari pertama. Sedangkan memiliki RD Stage I sebanyak 24 orang $(68,6 \%)$ pada hari ketiga, sebanyak 23 orang $(65.7 \%)$ pada hari kedua, sebanyak 18 orang $(51.4 \%)$ pada hari pertama, sebanyak 13 orang $(37,1 \%)$ pada hari keempat dan sebanyak 1 orang $(2.9 \%)$ pada hari kelima.

Table 4.7

Nilai-2 log likelihood

\begin{tabular}{|l|c|c|c|}
\hline Step & $\begin{array}{c}-2 \text { Log } \\
\text { likehood }\end{array}$ & $\begin{array}{c}\text { Cox \& Snell } \\
\text { R Square }\end{array}$ & $\begin{array}{c}\text { Nagelkerke R } \\
\text { Square }\end{array}$ \\
\hline 1 & $38.030^{*}$ & .382 & .775 \\
\hline
\end{tabular}

a. Estimation terminated at iterationh number 7 because parameter estimates changed by less than .001 .

Berdasarkan data pada Tabel 4.7 diperoleh Nilai $-2 \quad \log$ likelihood akhir diperoleh niiai $-2 \log$ likelihood sebesar 38,030. Hal ini memungkinkan adanya hubungan antara variabel bebas dengan variabel terikatnya. Nilai dari Nagelkerke R Square sebesar 0,775, hal ini berarti 77,50\% Penurunan Tekanan Darah Diastolik Lansia Penderita Hipertensi Di Puskesmas Muliorejo dapat dipengaruhi oleh pemberian Teknik Relaksasi Otot Progresif sedangkan sisanya $22,50 \%$ dipengaruhi oleh variabel lain diluar penelitian ini. 
Uji kemaknaan koefisien regresi secara keseluruhan (overall model) dari 4 secara keseluruhan dilakukan dengan menggunakan omnibus test of coefficient.

Tabel 4.8

Omnibus Test Of Model Coefficient

\begin{tabular}{|lc|r|r|r|}
\hline & & Chi-square & df & \\
\hline Step 1 & Step & 21.637 & 4 & .001 \\
& Block & 21.637 & 4 & .001 \\
& Model & 21.637 & 4 & .001 \\
& & & & \\
\hline
\end{tabular}

Hasil pengujian omnibus test of model coefficient diperoleh bahwa nilai chi (penurunan nilai2 log likelihood) sebesar 21,637 dengan nilai signifikan 0,001. Dengan nilai -2 Log Likelihood Value block number $=0$ lebih besar dari nilai -2 Log Likelihood Value block number $=1$ maka model regresi semakin baik. Dengan nilai signifikan yang lebih kecil dari 0,05 maka dapat disimpulkan tahun sebelumnya.

Hal ini berarti bahwa penggunaan variabel bebas dalam penelitian secara bersama-sama dapat menjelaskan terjadinya terhadap penurunan tekanan darah pada lansia penderita hipertensi di Puskesmas Muliorejo. Hasil ini menjelaskan bahwa hipotesis penelitian dapat diterima dan terbukti kebenarannya yaitu Pemberian Teknik Relaksasi Otot Progresif Terhadap Penurunan Tekanan Darah Pada Lansia Penderita Hipertensi Di Puskesmas Muliorejo Hasil analisis ini menggunakan uji regresi logistik, sehingga diketahui variabel paling dominan yang mempengaruhi Pemberian Teknik Otot Progresif Terhadap Penurunan Tekanan Darah Pada Lansia Hipertensi Di Puskesmas Muliorejo Tahun 2020.

\section{Pembahasan \\ Analisis Univariat}

Berdasarkan hasil penelitian pada Tabel 4.1 dapat diketahui umur pada penderita hipertensi di Puskesmas Muliorejo, dari 35 responden terdapat 18 responden $(56.47 \%)$ lanjut usia yaitu berumur $>66$ tahun dan terdapat 16 responden $(45.71 \%)$ lanjut usia yaitu berumur 46-65 tahun sedangkan terdapat 13 responden (56.47\%) berjenis kelamin Pria dan terdapat 17 responden $(43.63 \%)$ berjenis kelamin perempuan. Mayoritas lanjut usia yang mengalami hipertensi primer berusia antara $>66$ tahun. Karena pada usia tersebut, kelenturan dari arteri besar muiai menghilang dan menjadi kaku. Darah pada setiap denyut jantung dipaksa melewati ruang pembuluh darah yang sempit daripada biasanya dan inilah yang menyebabkan peningkatan tekanan darah (Sigarlaki, 2016).

Kuntjoro (2012) proses menua pada adalah proses alami yang disertai adanya penurunan kondisi fisik, termasuk tekanan darah yang tidak stabil.
Penelitian Agrina (2011) umur penderita hipertensi di Kelurahan Sidomulyo Barat Kota Pekanbaru, 33 responden $(55 \%)$ yang berumur 51 - 65 tahun.

Distribusi responden berdasarkan jenis kelamin diketahui perempuan lebih banyak baik. Tambayong (2016) menjelaskan insiden hipertensi pada perempuan tinggi dari laki-laki dikarenakan fungsi hormon esterogen pada wanita usia pertengahan mulai menurun, dimana hormon ini berperan dalam meningkatkan kadar HDL (High Density Lipoprotein), yang merupakan faktor pelindung terjadinya arterosklerosis. Penelitian Putri (2014) menyebutkan dari 82 responden penelitian $(57,3 \%)$ adalah perempuan yang mengalami hipertensi.

\section{Analisa Bivariat \\ Tekanan Darah Sebelum Pemberian Teknik Relaksasi Otot}

Hasil penelitian menunjukkan bahwa sebagian besar responden berusia $>66$ tahun (lansia) yaitu sebanyak 18 orang (56.47\%). Hal ini sesuai dengan teori Potter dan Perry (2005) bahwa usia seseorang menunjukkan tanda kemauan dan kemampuan, ataupun aktivitas fisik karena semakin bertambahnya seseorang, maka semakin banyak transisi yang akan dihadapi, salah satunya perubahan kesehatan dan kemampuan fungsional. Hal ini dapat mengakibatkan timbulnya gangguan di dalam hal mencukupi kebutuhan hidupnya, sehingga dpat meningkatkan ketergantungan yang memerlukan bantuan orang lain (Tamher \& Noorkasiani, 2009). Dengan demikian peneliti berpendapat bahwa semakin bertambahnya usia seseorang berdampak pada penurunan fungsional anggota tubuh, sehingga dapat mempengaruhi tingkat aktivitas fisik lansia.

Berdasarkan hasil uji statistik pada kelompok perlakuan menunjukkan adanya perbedaan rata-rata tekanan darah sistolik dan diastolik sebelum dan sesudah melakukan relaksasi otot progresif selama 6 kali latihan selama 6 hari. Latihan relaksasi otot progresif yang mana gerakan-gerakan didalamnya juga bertujuan untuk menurunkan kecemasan, stres, dan menurunkan tingkat depresi. Penurunan tersebut akan menstimulasi kerja sistem saraf perifer (autonom nervous system) terutama parasimpatis yang menyebabkan vasodilatasi penampang pembuluh darah akan mengakibatkan terjadinya penurunan tekanan darah baik sistolik maupun diastotik (Pollock, \& Wilmore, 2008).

\section{Tekanan Darah Sesudah Pemberian Teknik Relaksasi Otot Progresif}

Diketahui bahwa sesudah dilakukannya relaksasi otot seluruhnya 35 orang $(100.00 \%)$ terdapat 8 orang $(22.9 \%)$ dikategorikan tekanan darah dalam kondisi Prehipertensi (sistolik 120-139 mmHg / distolik 80-89 $\mathrm{mmHg}$ ) dan diketahui nilai $\mathrm{t}_{\text {hitung }}$ lebih besar dari $t_{\text {tabel }}(7,589 \geq 1,812)$. Hal ini bertolak belakang dengan hasil penelitian pada kelompok kontrol, dimana pada preecontrol tidak terdapat penurunan tekanan darah yaitu kategori tekanan darah adalah grade 1. Menurut Joint National Commite 
(JNC) VII yang dikutip oleh Triyanto (2014) derajad hipertensi dengan kelompok high Prehipertensi yaitu sistolik 120-139 $\mathrm{mmHg}$ dan diastolik 80-89 $\mathrm{mmHg}$. Penurunan tekanan darah setelah diberi relaksasi dapat dipengaruhi oleh kebiasaan mengkonsumsi makanan. Hal ini sesuai dengan hasil temuan penelitian yang diperoleh hampir setengah responden memiliki makanan kesukaan setiap hari yaitu sayur-sayuran sebanyak 8 orang (40\%), dan hampir seluruh responden dalam keseharian tidak mengkonsumsi santan yaitu sebanyak 18 orang $(90 \%)$.

Berbagai cara dilakukan untuk menurunkan tekanan darah diantaranya dengan terapi farmakologis yang menggunakan berbagai macam obat maupun nonfarmakologis salah satunya dengan relaksasi otot progresif (Triyanto, 2014). Relaksasi otot progresif adalah latihan untuk mendapatkan sensasi rileks dengan menegangkan suatu kelompok otot dan menghentikan. Rangsangan pada sistem saraf simpatis meningkatkan aktifitas jantung, meningkatkan frekuensi jantung, dan menaikkan kekuatan pemompaan. Peningkatan kemampuan jantung dalam memompa darah untuk memenuhi kebutuhan tubuh terhadap oksigen, menyebabkan jantung tidak perlu berdenyut lebih cepat untuk dapat memompa darah dalam jumlah tertentu seperti sewaktu sebelum berolahraga teratur (Sherwood, 2006).

Berbagai cara dilakukan untuk menurunkan tekanan darah diantaranya dengan terapi farmakologis yang menggunakan berbagai macam obat maupun non farmakologis salah satunya dengan relaksasi otot progresif (Triyanto, 2014). Relaksasi otot progresif adalah latihan untuk mendapatkan sensasi rileks dengan menegangkan suatu kelompok otot dan menghentikan tegangan (Mashudi, 2010).

\section{Pengaruh Teknik Relaksasi Terhadap Penurunan Hipertensi}

Terdapat hubungan langsung antara peningkatan pemasukan oksigen saat mengerahkan tenaga dengan peningkatan denyut jantung. Denyut jantung meningkat pada saat tubuh melakukan aktivitas lebih dan pernafasan juga meningkat untuk memenuhi kebutuhan oksigen pada metabolisme tubuh. Pada prinsipnya semakin rendah kecepatan denyut jantung waktu istirahat, maka semakin baik bentuk jantung. Jadi supaya lebih bugar, kecepatan denyut jantung waktu istirahat harus menurun (Suhardjono, 2014).

Tekanan darah menggambarkan interelasi dari curah jantung, tahanan vaskuler perifer, volume darah, viskositas darah dan elastisitas arteri. Tekanan darah bergantung pada curah jantung dan tahanan perifer. Faktor-faktor yang turut mempengaruht tekanan darah adalah faktor genetik, usia, stres, dan gaya hidup. Tekanan darah dewasa cenderung meningkat dengan pertambahan usia. Ansietas, takut, nyeri dan stres emosi mengakibatkan stimulasi simpatik, yang meningkatkan frekuensi denyut jantung, curah jantung, dan tahanan vaskuler perifer karena menimbulkan stimulasi simpatik sehingga meningkatkan tekanan darah (Potter \& Perry, 2005).
Hasil penelitian ini sejalan dengan penelitian sebelumnya yang diiakukan oleh Valentine, dkk. (2014), didapatkan hasil bahwa dengan relaksasi otot progresif terbukti tekanan darah pada penderita hipertensi dapat menurun. Penelitian lain oleh Patel, dkk (2012) juga menunjukkan adanya penurunan tekanan darah pada penderita hipertensi essensial dengan dilakukannya relaksasi otot progresif. Dengan demikian dapat dikatakan bahwa orang yang dengan risiko hipertensi, tekanan darahnya dapat distabilkan dengan melakukan relaksasi otot.

\section{KESIMPULAN}

Dari hasil penelitian tentang Pengaruh Pemberian Teknik Relaksasi Otot Progresif Terhadap Penurunan Tekanan Darah Pada Lansia Penderita Hipertensi Di Puskesmas Muliorejo, dapat ditemukan suatu hasil kesimpulan, yaitu :

1) Sebelum dilakukannya relaksasi otot terdapat 22 orang $(62.9 \%)$ dikategorikan mengalami hipertensi dengan tingkat Stage 1 (sistolik 140-159 mmHg / distolik 90-99 mmHg).

2) Sesudah dilakukannya relaksasi terdapat 8 orang (22.9\%) dikategorikan tekanan darah dalam kondisi normal yaitu tekanan darah Prehipertensi (sistolik 130$139 \mathrm{mmHg} /$ distolik 80-89 $\mathrm{mmHg}$ ).

3) Terdapat pengaruh teknik relaksasi otot progresif terhadap penurunan hipertensi pada lansia di Puskesmas Muliorejo yang dibuktikan dengan nilai Sig. $=0,000$

\section{Daftar Pustaka}

Agrina (2011). Kepatuhan Lansia Penderita Hipertensi Dalam Pemenuhan Diet Hipertensi. Jurnal Vol.6, No.1, April 2011:46 ISSN 1907-364X.

Dinas Kesehatan Sumatera Utara. (2017). Kesehatan Provinsi Sumatera Utara. 2017.

Fitrianti, S. dkk. (2018). Pemberian Relaksasi Otot Progresif pada Lansia dengan Hipertensi di Kota Jambi Salvita Fitrianti 1, Miko Eka Putri Program Studi Ilmu Keperawatan Stikes Baiturrahim Jambi 1, 18(2), 368-374.

Kementrian Kesehatan RI. (2017). Situasi Lansia di Indonesia Tahun 2017 Indonesia Gambar Struktur Umur Penduduk Indonesia Tahun 2017.

Kesehatan Kota Binjai. (2016). Profil Kesehatan Kota Medan.

Kesehatan, P., \& Medan, K (2016). Profil Kesehatan Kota Medan.

Khairiyah Wahyuningsih, H (2018). Pengaruh Relaksasi Otot Progresif Terhadap Penurunan Tekanan Darah pada Lansia Penderita Hipertensi di Posyandu Lansia Purwodiningratan Jebres.

Kuntjoro Z., 2012. Memahami Mitos dan realita Tentang lansia. E-psikologi.com. 
Nursyahidah, A. (2016). Pengaruh Teknik Relaksasi Progresif Terhadap Perubahan Tekanan Darah Pra Lansia Penderita Hipertensi di RW 24 Kelurahan Pringgokusuman Gedong Tengen Yogyakarta. (http://abu farhanalir.blogspot.com/2015/03/ terapirelaksasi-otot-progresif-bagi.html).

Putri,R. (2014). Hubungan Antara Tingkat Pengetahuan tentang Diet Hipertensi dengan Kejadian Kekambuhan Hipertensi Lansia di Desa Mancasan Wilayah Kerja Puskesmas I Baki Sukoharjo. Naskah Publikasi, FIK UMS Surakarta.

Rismawati. (2013). Profil Tekanan darah pada lansia di Panti Sosial Tresna Werdha Sabai nan aluih, 1-7 (https:doi.org/10.1086/513446. lijima).

Soekidjo Notoatmodjo. (2017). Metodologi Penelitian Kesehatan (1st ed) Jakarta : PT Rineka Cipta.
Tambayong, J. (2016) Patofisiologi untuk Keperawatan. Jakarta : EGC.

Tyani S, E. dkk. (2015). Efektivitas Relaksasi Otot Progresif Terhadap Tekanan Darah pada Penderita Hipertensi Esensial, 2 (2).

Ulya Inayatul, Z., \& Faidah, N. (2017). Pengaruh Terapi Relaksasi otot Progresif Terhadap Penurunan Tekanan Darah pada Penderita Hipertensi di Desa Koripandriyo Kecamatan Gabus kabupaten Pati, 6. 